\title{
Peroxynitrite and Nitric Oxide Donors Induce Neuronal Apoptosis by Eliciting Autocrine Excitotoxicity
}

\author{
Marcel Leist ${ }^{1}$, Eugenio Fava ${ }^{1}$, Cesare Montecucco ${ }^{2}$ and Pierluigi ${ }^{1}$ Nicotera \\ ${ }^{1}$ Chair of Molecular Toxicology, Faculty of Biology, University of Konstanz, Box 5560-X911, D-78457 Konstanz, Germany \\ ${ }^{2} \mathrm{CNR}$ Centre for Biomembranes and Department of Biomedical Sciences, University of Padua, Italy
}

Keywords: apoptosis, mouse, clostridial neurotoxins, peroxynitrite, NMDA receptor

\begin{abstract}
Endogenous generation of nitric oxide and its congeners, including peroxynitrite (ONOO-), has been implicated in the mechanism of neuron loss in neurodegenerative diseases. Accordingly, nitric oxide donors and $\mathrm{ONOO}^{-}$ can elicit both apoptosis and necrosis in neuron cultures. Here we show that nitric oxide donors and $\mathrm{ONOO}^{-}$are each able to trigger apoptosis of mouse cerebellar granule cells by an excitotoxic mechanism requiring exocytosis and NMDA receptor-mediated intracelluiar $\mathrm{Ca}^{2+}$ overload. This conclusion is supported by the following findings. Apoptosis was induced by various nitric oxide donors or by direct addition of $\mathrm{ONOO}^{-}$to differentiated cerebellar granule cell cultures that were sensitive to NMDA toxicity, but not in cerebellar granule cells that did not display NMDA-induced cell death (i.e. early days in culture) or in various glial cell populations. Donors of ONOO- or nitric oxide stimulated a sustained increase in intracellular $\mathrm{Ca}^{2+}$, which was prevented by inhibitors of NMDA receptors, such as MK-801 and 5-phospho-aminovaleric acid, or by dampening neuronal electrical activity with high concentrations of extracellular $\mathrm{Mg}^{2+}$. Moreover, these treatments and the exposure of cerebellar granule celis in nominaliy $\mathrm{Ca}^{2+}$-free media prevented apoptotic cell death. Both the intraceliular $\mathrm{Ca}^{2+}$ increase and apoptosis elicited by $\mathrm{ONOO}^{-}$or the nitric oxide donors were prevented by blocking exocytosis with tetanus toxin or botulinum neurotoxin $\mathrm{C}$.
\end{abstract}

\section{Introduction}

Nitric oxide is a pleiotropic messenger in the central nervous system (Garthwaite and Boulton, 1995). It exerts physiological effects by regulating guanylate cyclase activity or possibly by mild, partially reversible, covalent protein modifications, such as $S$-nitrosylation (Stamler et al., 1992a,b; Stamler, 1994). Under pathophysiological conditions (Crow and Beckman, 1995; Gross and Wolin, 1995) inappropriate production of nitric oxide may be involved in neurotoxicity (Dawson et al., 1991; Zhang and Snyder, 1995). The targets and mechanisms of these adverse effects of nitric oxide are commonly thought to be different from those involved in its physiological actions. They may include DNA damage and irreversible protein modifications such as tyrosine nitration or thiol oxidation.

Enzymatically produced nitric oxide may undergo a large variety of non-enzymatic reactions e.g. with cellular thiols, metals or with superoxide $\left(\mathrm{O}_{2}^{--}\right)$. Products formed from these secondary reactions may have biological activities that differ considerably, which have been elucidated only in part (Lipton et al., 1993; Stamler, 1994; Garthwaite and Boulton, 1995; Zhang and Snyder, 1995). In particular, peroxynitrite $\left(\mathrm{ONOO}^{-}\right)$, formed by the reaction of $\mathrm{NO}^{\circ}$ with $\mathrm{O}_{2}{ }^{\cdots}$, has been implicated in cortical neuronal apoptosis (Bonfoco et al., 1995; Dawson et al., 1993), and as inducer of apoptosis in various cell lines (Estévez et al., 1995; Lin et al., 1995; Troy et al., 1996). $\mathrm{ONOO}^{-}$can nitrate or hydroxylate protein tyrosine residues (Ischiropoulos et al., 1992; Beckmann et al., 1994; Crow and
Beckman, 1995), it oxidizes thiols (Radi et al., 1991; Stamler et al., 1992a), and decomposes into $\mathrm{OH}^{+}$and $\mathrm{NO}_{2}{ }^{*}$ at neutral pH (Beckman et al., 1990; Beckman et al., 1995; Crow and Beckman, 1995). In neurons, the targets of $\mathrm{ONOO}^{-1}$ have been identified only partially. Possible cytotoxic mechanisms involve DNA damage and the activation of poly-(ADP-ribose) synthase with subsequent depletion of NAD and ATP (Zhang et al., 1994), or mitochondrial damage (Bolanos et al., 1995).

An entirely different paradigm of nitric oxide toxicity is based on its presynaptic actions. Nitric oxide is known to stimulate neurotransmitter release (O'Dell et al., 1991; Hirsch et al., 1993; Meffert et al., 1994). Recently, it has been shown that nitric oxide stimulates exocytosis of neurotransmitters from synaptic vesicles probably by $S$-nitrosylating proteins responsible for the fusion of neurosecretory vesicles with the plasma membrane (Meffert et al., 1996). In previous work we have also observed that NMDA receptor blockers prevent the toxicity of nitric oxide donors to cerebellar granule cells (CGC) (Bonfoco et al., 1996). Therefore, it scems conceivable that nitric oxide elicits apoptosis by stimulating the exocytosis of excitotoxic neurotransmitters. This would imply that the mechanisms underlying the physiological and toxic actions of nitric oxide on neurons may involve, at least in part, similar pathways (e.g. neurotransmitter release by controlled $S$-nitrosylation of fusion proteins). In this casc, the final outcome would be determined by the intensity of the insult 
or by the metabolic condition of the cell. In several pathological situations, e.g. hypoxia (Rothman, 1984; Drejer et al., 1985), hypoglycaemia (Wieloch, 1985; Sandberg et al., 1986) and various forms of intoxication (Bagetta et al., 1990; Turski et al., 1991; Ishimaru et al., 1992), unbalanced release of excitatory neurotransmitters seems to contribute significantly to toxicity, since NMDA receptor antagonists have proved to be neuroprotective. In line with such findings, we have shown (Bonfoco ef al., 1996) that inhibitors of NMDA receptors [MK-801 and D-2-amino-5-phosphonovaleric acid (APV)] prevent the characteristic series of events leading to the apoptosis of CGC after exposure to $S$-nitrosocysteine or $S$-nitrosoacetyl-penicillamine (SNAP). In the present study, we investigate the role of an autocrine excitotoxic mechanism in CGC apoptosis induced by nitric oxide donors or by direct exposure to ONOO-.

\section{Materials and methods}

\section{Materials}

Cell culture dishes were from Greiner (Frickenhausen, Germany) and cell culture media from Life Technologies (Eggenstein, Germany) or Biochrom (Berlin, Germany). The acetoxymethyl-ester of fluo-3 (Fluo-3-AM), calcein-AM, SYTOX, SNAP and H-33342 were from Molecular Probes (Eugene, OR). Peroxynitrite (Beckman et al., 1995), $S$-nitrosoglutathione (Hart, 1985) and S-nitrosocysteine (Lei et al., 1992) were synthesized and quantitated as described. ONOO' (in 600 $\mathrm{mM} \mathrm{NaOH}$ ) and $S$-nitrosoglutathione (dried powder) were stored at $-80^{\circ} \mathrm{C}$ under nitrogen for up to 6 weeks; S-nitrosocysteine was prepared freshly for each experiment. In control experiments, freshly prepared solutions were left to dissociate at neutral $\mathrm{pH}$ for $48 \mathrm{~h}$, and then showed no significant toxicily. Dichlorokynurenate and 6,7dichloroquinoxaline-2,3-dione were from Biomol (Hamburg, Germany). 1 $H[1,2,4]$ oxadiazole [4,3-a]quinoxalin-1-one was from Alexis (Grüinberg, Germany). Benzamide was from Aldrich (Steinheim, Germany), and trans-pyrrolidine dicarboxylic acid were from RBI (Cologne, Germany). Clostridium botulinum neurotoxin serotype C and tetanus toxin were purified as described (Schiavo and Montecucco, 1995). Solvents and inorganic salts were from Merck (Darmstadt, Germany) or Riedel-de Haen (Seclze, Germany). All other reagents not further specified were from Sigma.

\section{Animals}

Eight-day-old (for CGC) and 2-day-old (for glial cell cultures), specific pathogen-free BALB/c mice were obtained from the Animal Unit of the University of Konstanz. All experiments were performed in accordance with international guidelines to minimize pain and discomfort (US National Institutes of Health guidelines and European Community Council Directive 86/609/EEC)

\section{Cell cultures}

The CGC were prepared as described by Dreyer et al. (1985). Neurons were plated on dishes coated with $50 \mu \mathrm{g} / \mathrm{ml}$ poly-L-lysine (molecular weight $>300 \mathrm{kDa}$ ) at a density of $\sim 0.2 \times 10^{6} \mathrm{cells} / \mathrm{cm}^{2}(640000$ cells $/ \mathrm{ml}, 500 \mu \mathrm{l} /$ well in 24-well plates) and cultured in Eagle's Basal Medium (BME, Gibco) supplemented with $10 \%$ heat-inactivated fetal calf serum, $25 \mathrm{mM} \mathrm{KCl}, 2 \mathrm{mM} \mathrm{L}$-glutamine and penicillinstreptomycin. Forty-eight hours after plating, cytosine arabinoside $(10 \mu \mathrm{M})$ was added to the cultures. Neurons were routinely used at $8-10$ days in vitro (DIV) unless otherwise indicated. The frequency of glial fibrillary acid protein-positive cells was $<5 \%$. Cultures were ustally exposed to nitric oxide donors in their own medium, or occasionally in controlled salt solution (CSS) ( $\mathrm{NaCl}, 120 \mathrm{mM}$;

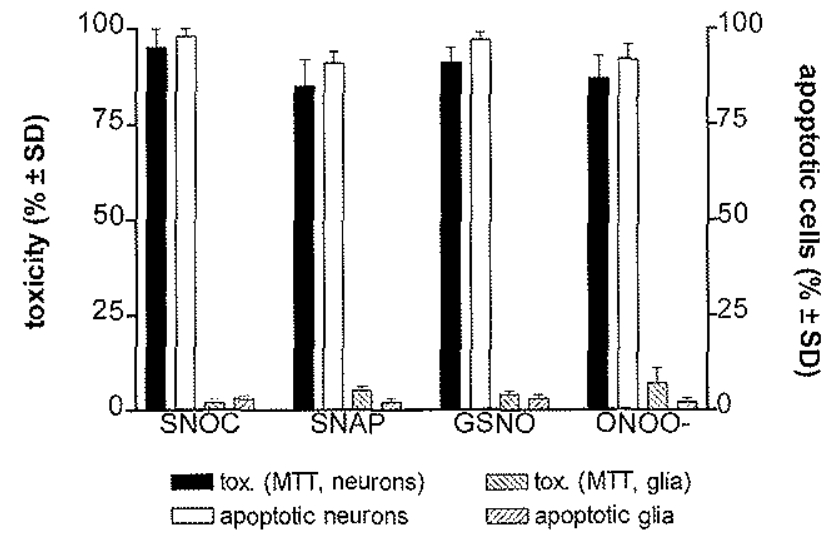

Fls. 1. Induction of CGC apoptosis by nitric oxide donors and ONOO*. Cultures of CGC (9 DIV) were exposed to $50 \mu \mathrm{M} S$-nitrosocysteine (SNOC), SNAP, S-nitrosoglutathione (GSNO) or $\mathrm{ONOO}^{-}$. Astroglial cultures werc exposed to $150 \mu \mathrm{M}$ of the nitric oxide donors or $\mathrm{ONOO}^{-}$. Toxicity was determined after $16 \mathrm{~h}$ by counting apoptotic nuclei ( $\mathrm{H}-33342 \mathrm{stain}$ ) or by the MTT assay. Data are mean $\pm \mathrm{SD}$ of धiplicate determinations.

HEPES, $25 \mathrm{mM}$; glucose, $15 \mathrm{mM} ; \mathrm{KCl}, 30 \mathrm{mM} ; \mathrm{CaCl}_{2}, 0-1.8 \mathrm{mM}$, $\mathrm{Mg}^{2+}, 0-0.5 \mathrm{mM}$; glycine, $0.01 \mathrm{mM}$ ) as indicated. $S$-nitrosocysteine was diluted for most experiments so that the working solution contained $0.05-0.25 \mathrm{mM} \mathrm{HCl}$. For exposure to $\mathrm{ONOO}^{-}$we devised a protocol involving addition of small amounts of acid $(\mathrm{HCl})$ sufficient to prevent alkalinization from the $\mathrm{ONOO}^{-}$stock solution. This procedure prevents putative receptor desensitization due to transient alkalinization. Solvents alone did not affect neuron survival even after continued culture for 6 days. Inhibitors were added routinely 10 min before exposure to nitric oxide donors. Glial cells were prepared as described (Hansson and Rönnbäck, 1989) and cultured in BME supplemented with $10 \%$ heat inactivated fetal calf serum. Cerebellar oligodendrocytes and primary murine microglia were kindly provided by Dr M. Jung (Konstanz) and Dr C. Nolte (Bertin), respectively.

In some experiments, polylysine coating was applied to a small area $\left(\sim 1 \mathrm{~mm}^{2}\right)$ within the culture well. Thirty minutes after plating, non-adherent cells were washed away to leave only a small patch of neurons $(500-1000)$ on the polylysine spot. Although the total number of neurons within the dish was $\leqslant 0.5 \%$ of the normal number, the density of cells within the patch and the formation of the axonal/ dendritic network after 8 DIV was similar to that in normally coated culture wells.

\section{Microscopy}

Cells stained with different filorescent probes were imaged in a Leica DM-IRB microscope equipped with a video camera or connected to a TCS-4D UV/VIS confocal scanning system.

\section{Measurement of $\left[\mathrm{Ca}^{2+}\right]$}

Dynamic changes of the intracellular $\mathrm{Ca}^{2+}$ concentration $\left(\left[\mathrm{Ca}^{2+}\right]_{\mathrm{i}}\right)$ were measured by imaging individual neurons loaded with a fluorescent $\mathrm{Ca}^{2+}$ indicator. Cells grown on plastic dishes were loaded in heir original medium with $1 \mu \mathrm{M}$ Fluo-3-AM for $15 \mathrm{~min}$ at $37^{\circ} \mathrm{C}$. Then the medium was exchanged for CSS (with $0.5 \mathrm{mM} \mathrm{Mg}^{2+}, 1.8$ $\mathrm{mM} \mathrm{CaCl}, 30 \mathrm{mM} \mathrm{KCl}$ ), and CGC were incubated for $10 \mathrm{~min}$ to allow complete de-esterification of fuo-3. The medium was then replaced with the original neuron-conditioned complete BME nedium supplemented with $20 \mathrm{mM}$ HEPES. The CGC were allowed to 

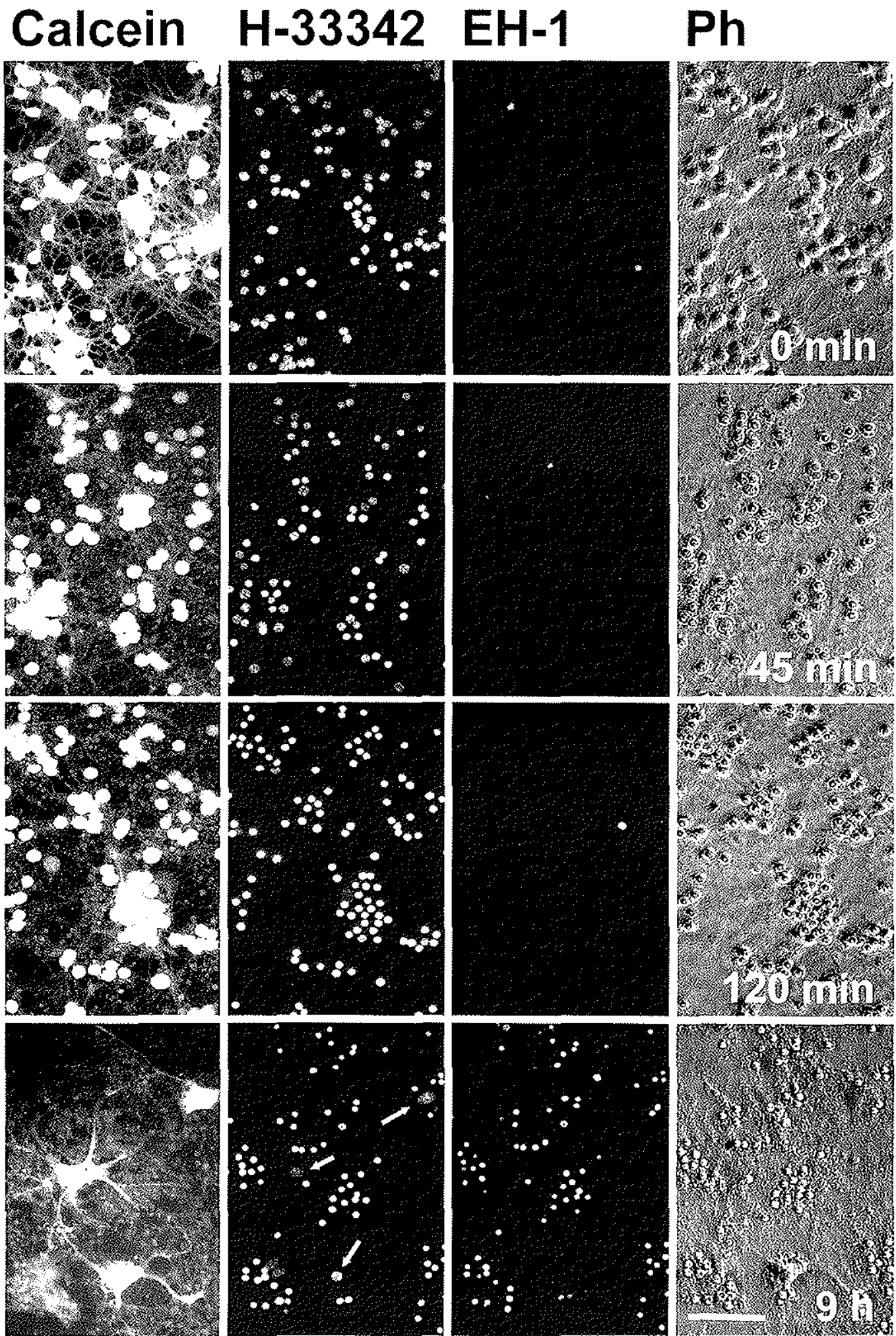

FiG. 2. Kinetics of cellular changes induced by exposure of CGC 10 ONOO-. Parallel CGC cultures were exposed to $50 \mu \mathrm{M}$ ONOO-* and stained with three ffuorescent markers 5 min before observation. At each time point a group of neurons was imaged sequentially under phase-contrast optics (Ph) and with threc fiuorescent filter sets (red fluorescence. EH-1; blue fluorescence, $\mathrm{H}-33342$; green fluorescence, calcein-AM). After 45 min $50 \%$ of the neuronal bodies were clearly condensed and hyperfuorescent. After $120 \mathrm{~min}$ all neuronal nuclei were condensed but still excluded Eh-1, and virtually all neurons accumulated calcein. After $9 \mathrm{~h}$, neuronal membranes were broken but the muclei did not detach from the culture dishes. Notably, the glial cells (arrows) in the field were not damaged (calcein retention, no condensation or EH-1 staining of their nuclei). Scale bar, $50 \mu \mathrm{m}$. 

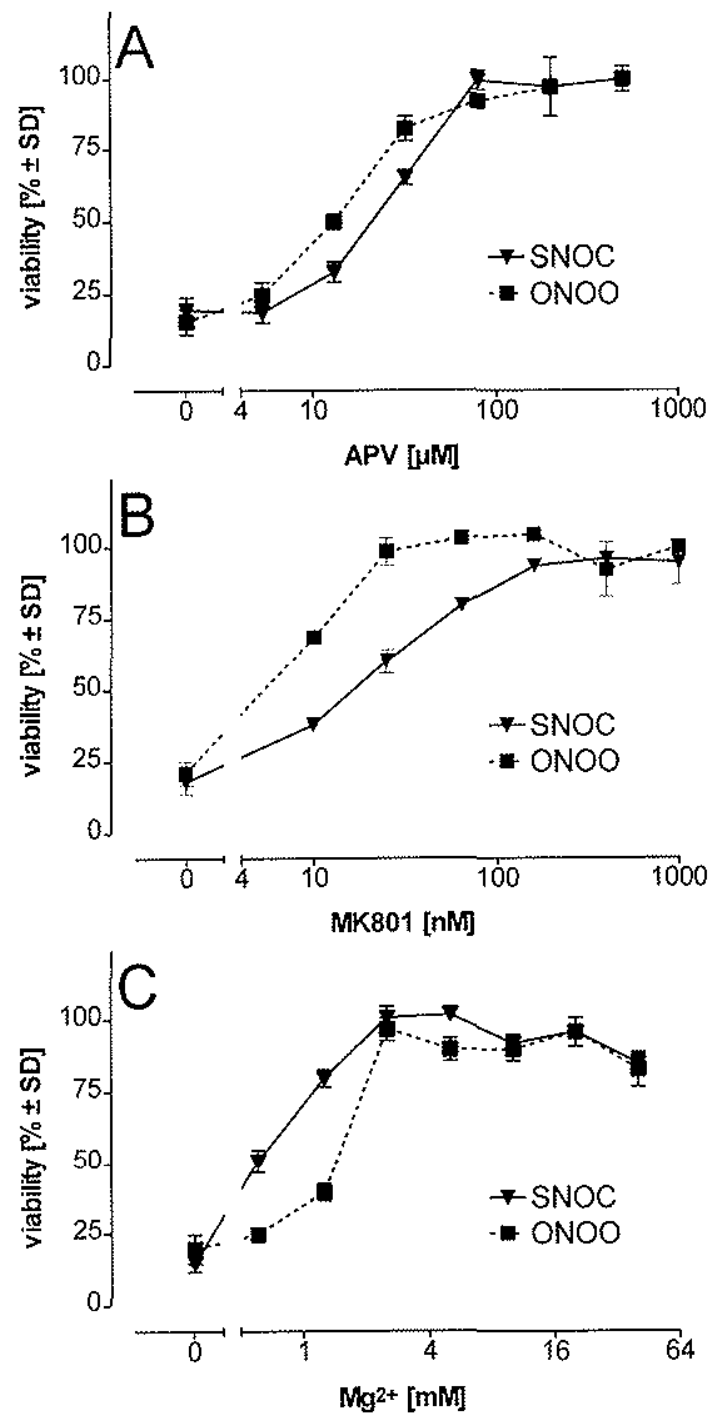

FIG. 3. Prevention of nitric oxide/ONOO- toxicity by NMDA receptor antagonisis. Cerebellar gxamule cells were incubated with inhibitors for 30 min, before $S$-nitrosocysteine (SNOC; $10 \mu \mathrm{M}$ ) or $\mathrm{ONOO}^{-}(50 \mu \mathrm{M})$ was added. Viability was determined after $16 \mathrm{~h}$ by the MTT assay. Data are mean $\pm \mathrm{SD}$ of triplicate determinations.

equilibrate at room temperature for $10 \mathrm{~min}$ before exposure to $\mathrm{ONOO}^{-}$ or to nitric oxide donors. Images were collected using $488 \mathrm{~nm}$ excitation and $520 \mathrm{~nm}$ emission wavelengths with a Leica DM-IRB microscope equipped with a $40 \times$ lens at intervals of $10 \mathrm{~s}$ (for nitric oxide donors) or $2 \mathrm{~s}$ (for chemical depolarization, i.e. addition of 50 $\mathrm{mM} \mathrm{KCl}$ ). The integration period was $100 \mathrm{~ms}$ per image with a Dage72 (Dage-MTI, Michigan City, IN) CCD camera 7756 (horizontal) $\times$ 581 (vertical) pixels]. Data were analysed using software from Imaging Corporation (St Catherines, Ontario, Canada). Relative mean fuorescence levels from defined areas corresponding to the position of neuronal cell bodies were recorded over $30 \mathrm{~min}$ and further processed using Excel 5.0 software (Microsoft). The mean fluorescence level of each marked cell was arbitrarily set to 1 at the beginning of each experiment. After each experiment, the increase in $\left[\mathrm{Ca}^{2+}\right]_{\mathrm{j}}$ triggered by $\mathrm{K}^{+}$depolarization $\left(50 \mathrm{mM} \mathrm{K}{ }^{+}\right)$was measured in order to determine the reactivity of the neurons and the validity of the experimental conditions.
Viability assays

To determine cell membrane integrity and nuclear changes, CGC were loaded with $1 \mathrm{mM}$ calcein-AM for 2 min (cells with intact membranes displayed green fluorescence) in the presence of $2 \mu \mathrm{M}$ ethidium homodimer-1 (EH-1) (cells with broken membranes exhibit ruclear red fluorescence) and $500 \mathrm{ng} / \mathrm{ml}$ of the bisbenzimide dye H33342 (cell-permeant, blue filorescence). Alternatively, apoptosis and secondary lysis were quantitated by double-staining neuron cultures with $1 \mu \mathrm{g} / \mathrm{ml} \mathrm{H}-33342$ and $1 \mu \mathrm{M}$ SYTOX (non-cell-permeant, green fluorescence). Apoptotic cells were characterized by condensed, highly fluorescent nuclei. In addition, the percentage of viable cells was quantitated by their capacity to reduce 3-(4,5-dimethylthiazole2-yl)-2,5-diphenyltetrasodium bromide (MTT) after incubation with $0.5 \mathrm{mg} / \mathrm{ml}$ MTT for $60 \mathrm{~min}$ (Mosmann, 1983). Reduction of MTT was usually measured $12-16 \mathrm{~h}$ after the treatments. For time-lapse experiments HEPES ( $\mathrm{pH} 7.3$, final concentration $20 \mathrm{mM}$ ) was added to the original culture medium. Cells were loaded for $15 \mathrm{~min}$ with $250 \mathrm{ng} / \mathrm{ml}$ Hoechst 33342 or used directly for phase-contrast microscopy. Control wells were always run on the same 24-well culture dish and scored after the end of the experiment. To quickly test membrane integrity at the end of these experiments, $90 \mu \mathrm{l}$ trypan blue $(0.4 \%)$ was added to cultures, which were bathed in $500 \mu \mathrm{l}$ of medium and left to incubate for $5 \mathrm{~min}$. After very gentle washing, trypan blue-positive cells were scored.

\section{Statistics}

Individzal experiments were run in triplicate. Traces of fiuo-3 fluorescence represented individual neurons, with 20-50 traces displayed per figure. Each of these experiments was repcated with at least three neuron preparations. Statistical significances were calculated on the original data sets using Student's $t$-test. When variances within the compared groups were not homogeneous we used the Welch test.

\section{Results}

\section{induction of cerebellar granule cells apoptosis by nitric oxide donors or ONOO-}

Exposure to various nitric oxide donors, i.e. S-nitrosocysteine, SNAP or S-nitrosoglutathione, resulted in CGC apoptosis (Fig. 1) with the typical features of nuclear pyknosis and chromatin condensation. Loss of MTT metabolizing activity (Fig. 1) as well as secondary membrane lysis (determined by the number of EH-1-positive nuclei) followed (Fig. 2). Mouse astroglial cultures were not affected by the same or three-fold higher concentrations of the nitric oxide donors (Fig. 1), even if exposure was prolonged for $48 \mathrm{~h}$. Also, nitric oxide donors were not toxic for a mouse cerebellar oligodendrocyte line or primary murine microglia cultures (data not shown).

$\mathrm{ONOO}^{-}$is generally considered as the terminal neurotoxic species formed from NO plus $\mathrm{O}_{2}{ }^{-*}$. Direct addition of this metabolite to CGC also elicited neuron death (Fig. 1). To further characterize the development of apoptosis induced by ONOO" or the nitric oxide donors we used time-lapse video microscopy (Fig. 2). Within 45$150 \mathrm{~min}$ after exposure to $\mathrm{ONOO}^{-}$or $S$-nitrosocysteine, $85-100 \%$ of all neuron nuclei condensed while the cell membrane remained intact. At the end of the experiment, i.e. after $150 \mathrm{~min}$, the large majority $(\geqslant 90 \%)$ of neurons with condensed nuclei excluded trypan blue or EH-1, and were able to accumulate calcein-AM. Membrane integrity was lost only several hours later, as determined in parallel cultures. Notably, apoptotic nuclei did not disintegrate and remained adherent to the culture plate together with the remnants of the neurons for $>24$ h (not shown). Virtually identical results were obtained with 

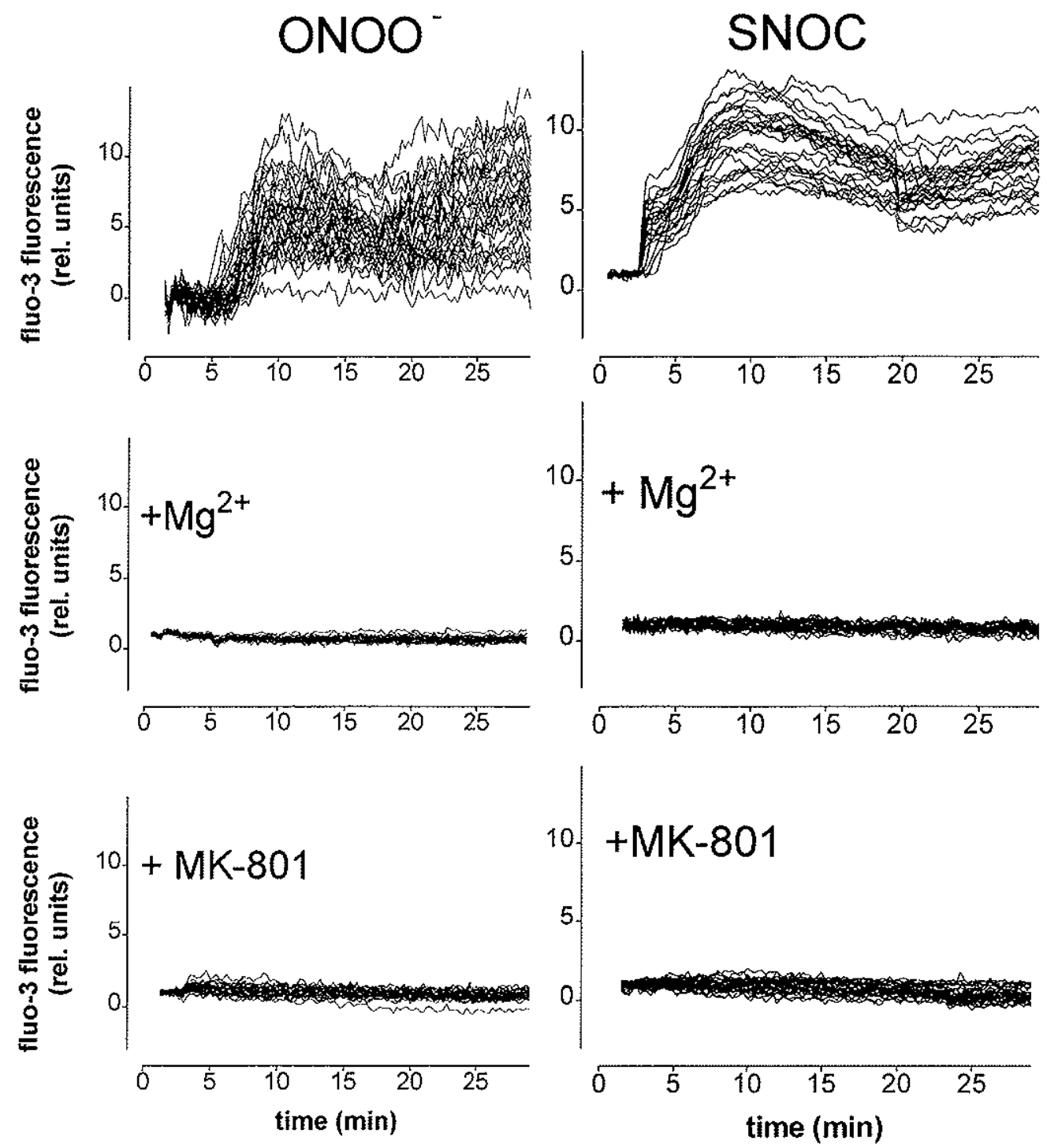

Fig. 4. Prevention of nitric oxide/ONOO-eliciled increases in $\left[\mathrm{Ca}^{2+}\right]_{i}$ by NMDA receptor inhibition. Cerebellar granule cells were loaded with fluo-3-AM for video imaging of $\left[\mathrm{Ca}^{2+}\right]_{\mathrm{i}}$. They were challenged with $88 \mu \mathrm{M}$ ONOO- or $50 \mu \mathrm{M} S$-nitrosocysteine (SNOC). MK- $801(2 \mu \mathrm{M})$ or $\mathrm{Mg}^{2+}(10 \mathrm{mM})$ was added 10 min before the stimuli. Each trace represents an individual cell body. Each set of data is from two or three experiments. All data presented in the figure are from the same cell preparation.

ONOO-- and $S$-nitrosocysteine. Figure 2 illustrates typical changes observed with ONOO".

The role of NMDA receptor in ONOO- and nitric oxideinduced apoptosis

We have previously observed that NMDA receptor antagonists protect rat CGC from $S$-nitrosocysteine-toxicity (Bonfoco et al., 1996). Here we examined whether such intervention would also prevent the toxicity of the putatively distal and direct mediator of toxicity, $\mathrm{ONOO}^{-3}$. A competitive (APV) as well as a non-competitive (MK801) inhibitor of the NMDA receptor prevented neurotoxicity of $\mathrm{ONOO}^{-}$(Fig. 3). Protection was complete, as pretreatment with MK801 allowed the survival of $\mathrm{ONOO}^{-}$-challenged neurons for at least $48 \mathrm{~h}$. To further examine whether excitotoxicity was the pivotal mechanism leading to $\mathrm{ONOO}^{-}$/nitric oxide toxicity, we increased the $\mathrm{Mg}^{2+}$ concentration in the medium. High $\left[\mathrm{Mg}^{2+}\right]$ dampens neuron activity and blocks the opening of NMDA receptor-gated $\mathrm{Ca}^{2+}$ channels (Monyer et al., 1992b; Rothman, 1983). This condition prevented the apoptosis induced by $S$-nitrosocysteine or $\mathrm{ONOO}^{-}$(Fig. 4). In addition, we used NMDA receptor inhibitors acting at the glycine costimulatory binding site ( $25 \mu \mathrm{M} 5,7-$ dichlorokynurenate or $80 \mu \mathrm{M}$ 6,7-dichloroquinoxaline-2,3-dione). Treatment with these agents reduced the toxicity of $50 \mu \mathrm{M} \mathrm{ONOO}^{-}$and $S$-nitrosocysteine by 45 and $55 \%$ respectively. The effective protection afforded by using competitive (APV) and non-competitive NMDA blockers and the similarity of the concentration response curves obtained with the inhibitors in $S$-nitrosocysteine or $\mathrm{ONOO}^{-}$treated neurons strongly suggest that these two agents acted by a common mechanism, e.g. by releasing an excitotoxic mediator that activates the NMDA receptor.

$\mathrm{ONOO}^{-}$and S-nitrosocysteine stimulate an increase in $\left.\mathrm{Ca}^{2+}\right]_{i}$ in cerebellar granule cells via the NMDA receptor

To test whether ONOO-- or the nitric oxide donors would elicit NMDA receptor-mediated $\mathrm{Ca}^{2+}$ influx, we measured $\left[\mathrm{Ca}^{2+}\right]_{i}$ in $\mathrm{CGC}$ 


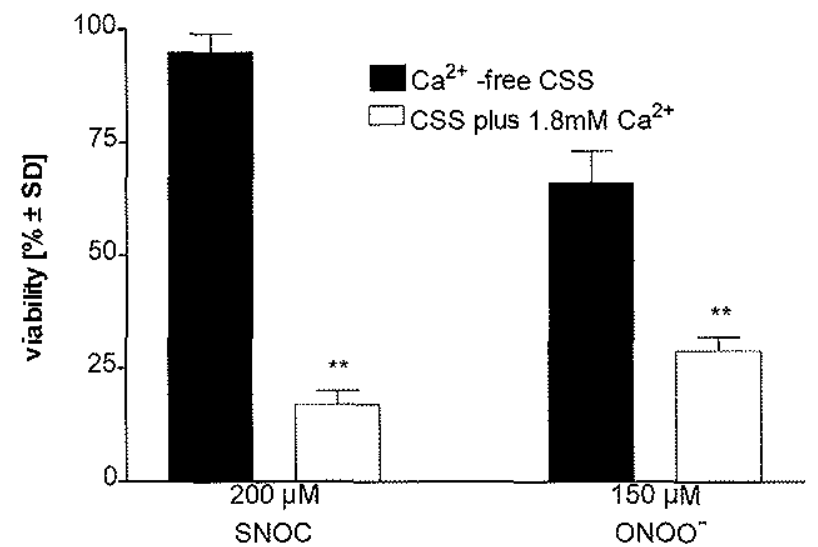

Fig. 5. Modulation of $S$-nitrosocysteine/ONOO" toxicity by the extracellular $\mathrm{Ca}^{2+}$ concentration. CGC were exposed to $S$-nitrosocysteinc (SNOC) or $\mathrm{ONOO}^{-}$for $3 \mathrm{~min}$ before the original medium was rapidly removed and replaced by CSS without added $\mathrm{Ca}^{2+}\left(\mathrm{Ca}^{2+}\right.$ free CSS $)$ or by CSS with 1.8 $\mathrm{mM}$ added $\mathrm{Ca}^{2+}$. Viability was determined after $16 \mathrm{~h}$ by MTT assay. Data are mean $\pm \mathrm{SD}$ from triplicate determinations. $* 2 p<0.01, \mathrm{Ca}^{2+}$-free versus $1.8 \mathrm{mM} \mathrm{Ca}^{2+}$.

immediately after the addition of $S$-nitrosocysteine or ONOO". Addition of $\mathrm{ONOO}^{-}$or $S$-nitrosocysteine elicited a rapid and sustained increase in $\left[\mathrm{Ca}^{2+}\right]_{i}$ that was entirely abolished by pre-treatment with high $\mathrm{Mg}^{2+}$, MK-801 (Fig. 4) or $500 \mu \mathrm{M}$ APV (not shown). Then, to determine whether $\mathrm{Ca}^{2+}$ influx was causally involved in the toxicity of nitric oxide, we assessed the toxicity of $S$-nitrosocysteine in CSS in the presence or absence of added $\mathrm{Ca}^{2+}(1.8 \mathrm{mM})$. When exposure to $S$-nitrosocysteinc was performed in nominally $\mathrm{Ca}^{2+}$-free conditions, toxicity was virtually abolished (70-95\% protection). Interestingly, when extracellular $\mathrm{Ca}^{2+}$ was removed after the addition of $S$ nitrosocysteine, toxicity was also reduced. A similar effect was observed with $\mathrm{ONOO}^{-}$(Fig. 5). In these experiments the original BME medium was replaced by CSS with or without $1.8 \mathrm{mM} \mathrm{Ca}^{2+1}$, 3 min after the addition of $\mathrm{ONOO}^{-}$(i.e. when most $\mathrm{ONOO}^{-}$was presumably dissociated). In line with these findings, the addition of $2 \mu$ M MK-801 2 min after treatment with $S$-nitrosocysteine or ONOOrescued $81 \pm 4$ and $46 \pm 5 \%$ of the neurons respectively.

\section{Dependence of $\mathrm{ONOO}^{-}$/nitric oxide-induced apoptosis on in vitro differentiation of cerebellar granule cells}

Cerebellar granule cells change functional properties, receptor expression and consequently sensitivity towards excitotoxic stimuli during maturation. After plating and for the first few days in vitro, CGC are not sensitive to NMDA toxicity (Frandsen and Schousboe, 1990; Piani et al., 1992; Rossi and Slater, 1993; Xia et al., 1995). Therefore we examined the toxicity of $S$-nitrosocysteine and $\mathrm{ONOO}^{-}$during in vitro differentiation of CGC. The lethal effects of NMDA, $S$-nitrosocysteine and $\mathrm{ONOO}^{-}$were strongly dependent on the developmental stage (Fig. 6). This was not due to general lability of the neurons caused by energy deprivation, since supplementation of the culture medium with $20 \mathrm{mM}$ glucose did not affect the toxicity of the nitric oxide donors, although it prolonged long-term survival of untreated cultures.

Similar sensitivity of DIV 5 and DIV 8 cultures to $200 \mu \mathrm{M}$ $\mathrm{ONOO}^{-}$but a large difference at lower concentrations suggests that qualitatively different pathways of nitric oxide toxicity exist in CGC. However, the finding that MK801 $(2 \mu \mathrm{M})$ and APV $(500 \mu \mathrm{M})$ are also effective (100\% protection) at concentrations up to $200 \mu \mathrm{M}$ $S$-nitrosocysteine/ONOO- $/ \mathrm{S}$-nitrosoglutathione suggests only a quant-
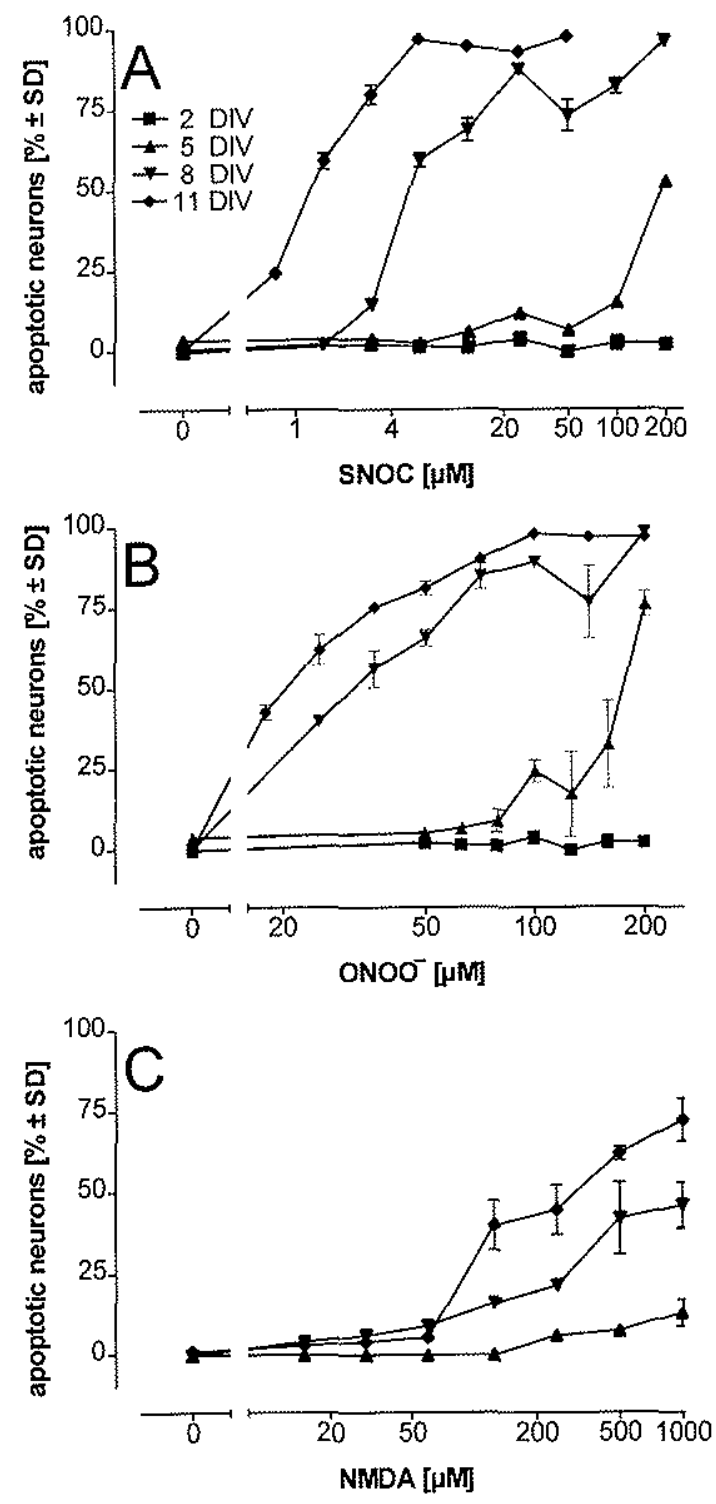

FIG. 6. Dependence of nitric oxide/ONOO-toxicity on the differentiation state of $\mathrm{CGC}$. The CGC were used at $2,5,8$ or $11 \mathrm{DIV}$. They were exposed to the indicated toxin concentrations for $24 \mathrm{~h}$ before they were fixed, stained with $\mathrm{H}-33342$ and scored for the percentage of apoptotic neurons. Parallel toxicity determinations with the MTT method yiclded essentially similar results. Data are mean $\pm \mathrm{SD}$ of triplicate determinations. SNOC, $S$-nitrosocysteine.

itative difference between the different cultures with respect to nitric oxide toxicity, i.c. DIV 5 cultures containing fewer synapses may require higher amounts of nitric oxide to release the same amount of neurotransmitter.

\section{Pharmacological characterization of nitric oxide-induced cerebellar granule cell apoptosis}

The sensitivity of nitric oxide-induced apoptosis to pharmacological agents known to affect other actions of nitric oxide was also tested. These experiments suggested that the toxicity of exogenous nitric oxide or $\mathrm{ONOO}^{-}$was dependent neither on de novo protein synthesis nor on guanylate cyclase activation (Garthwaite et al., 1995). Also, inhibitors of poly-(ADP-ribose) synthase were ineffective in this system (Table 1). In contrast, a protective effect was observed 
using an enzymatic system to remove glutamate (glutamate-pyruvate transaminase plus pyruvate). Thus, in accordance with previous reports on the activating action of nitric oxide on the vesicle fusion machinery (Meffert et al., 1994, 1996), $\mathrm{ONOO}^{-}$and nitric oxide donors may directly stimulate the release of glutamate from synaptic terminals.

\section{Endogenous mediator release and autocrine toxicity of nitric oxide and $\mathrm{ONOO}^{-}$in cerebellar granule cells}

To directly address the possibility that exocytosis of excitotoxic mediators is necessary for apoptosis induced by $S$-nitrosocysteine or $\mathrm{ONOO}^{--}, \mathrm{CGC}$ were treated with clostridial toxins which are known to impair exocytosis by cleaving vesicle-docking proteins. Pretreatment for $2-10 \mathrm{~h}$ with either tetanus toxin or botulinum neurotoxin $\mathrm{C}$ markedly reduced the neurotoxicities of $\mathrm{ONOO}^{-}$and $S$-nitrosocysteine (Fig. 7),

Subsequently we examined whether inhibition of nitric oxideinduced exocytosis was correlated with reduced NMDA receptor stimulation, and was thus excitotoxicity. Therefore we treated neurons with a combination of botulinum neurotoxin $\mathrm{C}$ (which cleaves the plasma membrane-docking protein syntaxin) and tetants toxin (which cleaves the vesicular docking protein synaptobrevin/VAMP) (Montecucco and Schiavo, 1995). This combination completely prevented $\mathrm{ONOO}^{-}$- and $S$-nitrosocysteine-induced apoptosis (Fig. 8) and significantly reduced the $\left[\mathrm{Ca}^{2+}\right]_{i}$ increase triggered by $S$-nitrosocystcine or $\mathrm{ONOO}^{-}$(Fig. 8). An important role for stimulated synaptic neurotransmitter release in CGC apoptosis was supported by the following observations. (i) Blocking glutamate uptake in otherwise unstimulated cultures with $15 \mu \mathrm{M}$ trans-pyrrolidine-2,4-dicarboxylate

TABLE 1. Pharmacological modulation of $\mathrm{ONOO}^{-/ S}$-nitrosocysteine toxicity

\begin{tabular}{|c|c|c|c|}
\hline \multirow[t]{2}{*}{ Intuibitor } & \multirow{2}{*}{$\begin{array}{l}\text { Concentration } \\
(\mu \mathrm{M})\end{array}$} & \multicolumn{2}{|c|}{ Inhibition of toxicity $(\% \pm \mathrm{SD})$ by: } \\
\hline & & $\begin{array}{l}\text { S-nitrosocystcine } \\
(10 \mu \mathrm{M})\end{array}$ & $\mathrm{ONOO}^{-}(50 \mu \mathrm{M})$ \\
\hline & $1-10$ & $<5$ & $<5$ \\
\hline Pyruvate & 10000 & $<5$ & $<5$ \\
\hline Pyruvate + GPT & $\begin{array}{l}10000 \text { plus } \\
25 \mathrm{U} / \mathrm{ml}\end{array}$ & $36 \pm 4 \%$ & $42 \pm 7 *$ \\
\hline Cycloheximide & $1-.50$ & $<5$ & $<5$ \\
\hline Actinomycin D & $0.1-10$ & $<5$ & $<5$ \\
\hline Benzamide & $500-2500$ & $10 \pm 5(2.5 \mathrm{mM})$ & $<5$ \\
\hline 3-Aminobenzamide & $500-2500$ & $<5$ & $<5$ \\
\hline Nicotinamide & $500-2500$ & $<5$ & n.d. \\
\hline Superoxide dismutase & $1000 \mathrm{U} / \mathrm{ml}$ & $54 \pm 6 \%$ & n.d. \\
\hline$N$-methyl arginine & $30-300$ & $<5$ & $<5$ \\
\hline
\end{tabular}

Cerebellar granule cells ( 9 DIV) were preincubated with the indicated concentrations of inhibitors for $30 \mathrm{~min}$ before $S$-nitrosocysteine or $O \mathrm{NOO}^{-}$ was added. Cytotoxicity (determined by MTT reduction after $16 \mathrm{~h}$ ) was $90 \%$ in cells pretreated with solvent controls (CSS or DMSO) only. n.d., not determined.

$* p \leqslant 0.05$
(Bridges et al, 1991) resulted in neuron death $(84 \pm 7 \%$ of neurons within $12 \mathrm{~h}$ ), which was completely blocked by MK-801. In this experimental paradigm of autocrine neuron death due to unstimulated neurotransmitter release, apoptosis of CGC was 5 times slower than that found after the putative triggering of exocytosis by nitric oxide. (ii) Neurons were seeded in small patches (i.e. the total number per culture dish was $>100$ times lower than normal) to test whether the toxicity of nitric oxide requires a general increase in excitatory neurotransmitter concentrations in the culture medium or whether a loca1 increase, possibly at synaptic clefts, is sufficient. Under these conditions $\mathrm{ONOO}^{-}$still induced $\mathrm{CGC}$ apoptosis, which was prevented by pretreament with clostridial toxins or MK-801 (89 \pm 4 and $98 \pm 3 \%$ of the neurons survived when patches were pretreated with clostridial toxins and MK-801, respectively).

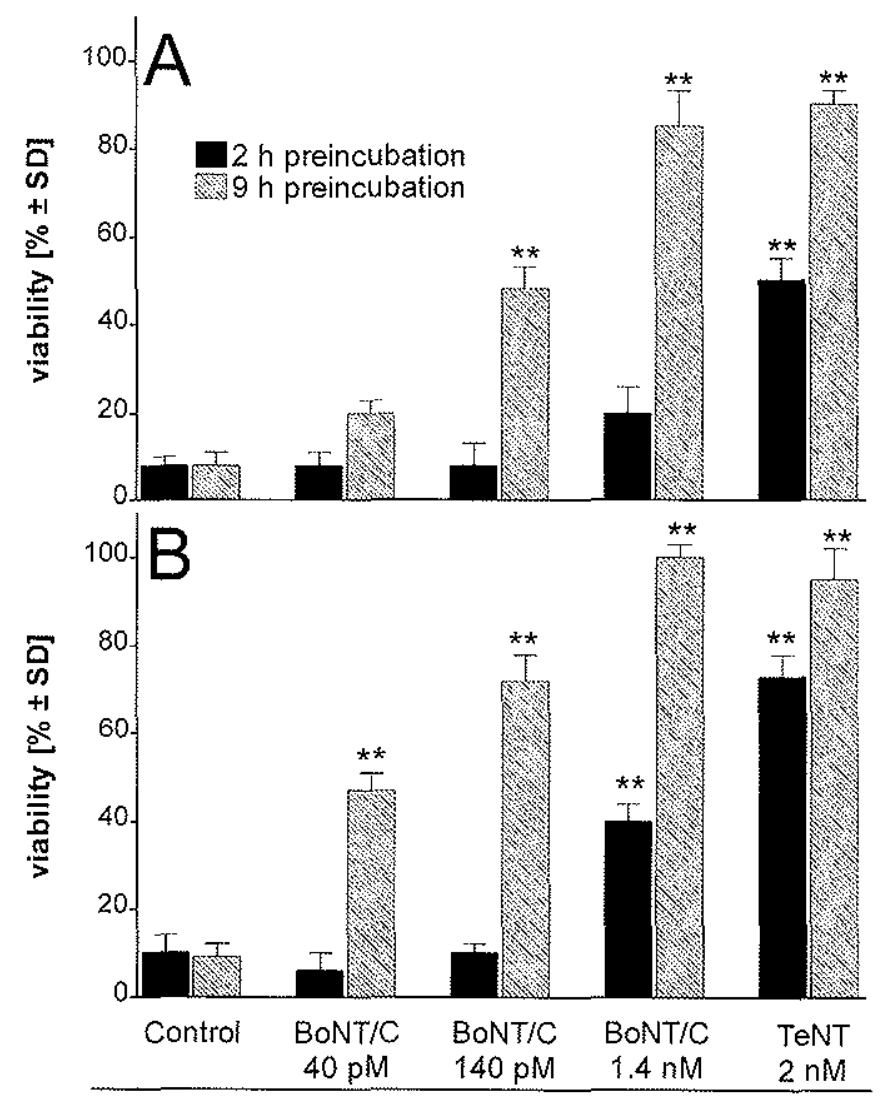

FIG. 7. Protcction of CGC from $S$-nitrosocysteine/ONOO- toxicity by clostridial neuroloxins. $C G C$ were preincubated with clostridial toxins as indicated and then challenged with $10 \mu \mathrm{M} S$-nitrosocysteine (A) or $80 \mu \mathrm{M} \mathrm{ONOO}^{-}$(B). Viability was determined $16 \mathrm{~h}$ later by the MTT method. Data arc mean \pm SD of triplicate determinations. $* * P<0.01$ versus control. BoNT/C, botulinum neurotoxin $\mathrm{C}$.

Fig. 8. Prevention of $S$-nitrosocysteine/ONOO-induced $\mathrm{CGC}$ apoptosis and $\left[\mathrm{Ca}^{2+}\right]_{i}$ increases by botulinum neurotoxin $\mathrm{C}$ plus tetanus toxin. $\mathrm{CGC}$ were loaded with fuo-3 for imaging of $\left[\mathrm{Ca}^{2+}\right]_{i}$ changes $(\mathrm{A}-\mathrm{D})$, or used directly for determination of apoptosis (E). Cultures werc challenged directly (A, $C$, $E$, top) or pretreated with $500 \mathrm{pM}$ botulinum neurotoxin $\mathrm{C}$ plus $5 \mathrm{nM}$ tetanus toxin for $5 \mathrm{~h}(\mathrm{~B}, \mathrm{D}, \mathrm{E}$, bottom), and then stimulated with either $50 \mu \mathrm{M} O \mathrm{NOO}-\mathrm{A}, \mathrm{B}, \mathrm{E})$ or with $25 \mu \mathrm{M} S$-nitrosocysteine (SNOC; C-E). The percentage of apoptosis was determined after staining with $\mathrm{H}-33342$ (E). Clostridial toxins prevented the formation of condensed and hyperfltorescent apoptotic nuclei in neurons challenged with $S$-nitrosocysteine or ONOO'. They also prevented a sustaincd increase in $\left[\mathrm{Ca}^{2+}\right]$, although occasionally a short, transient rise was observed. After termination of the $\left[\mathrm{Ca}{ }^{2+}\right]_{i}$ measurements $(\mathrm{A}-\mathrm{D})$ in $S-n$ itrosocysteine- or ONOOtreated cultures, the programme was immediately restarted (initial fuorescence levels set to 1 ) and changes in $\left[\mathrm{Ca}^{2+}\right]_{\mathrm{i}}$ due to depolatization with 50 mM $\mathrm{K}^{*}$ were recorded within the same cultures. Clearly delayed recovery was always observed in $S$-nitrosocysteine-treated neurons (C). Scale bar in E, $50 \mu$ m. 

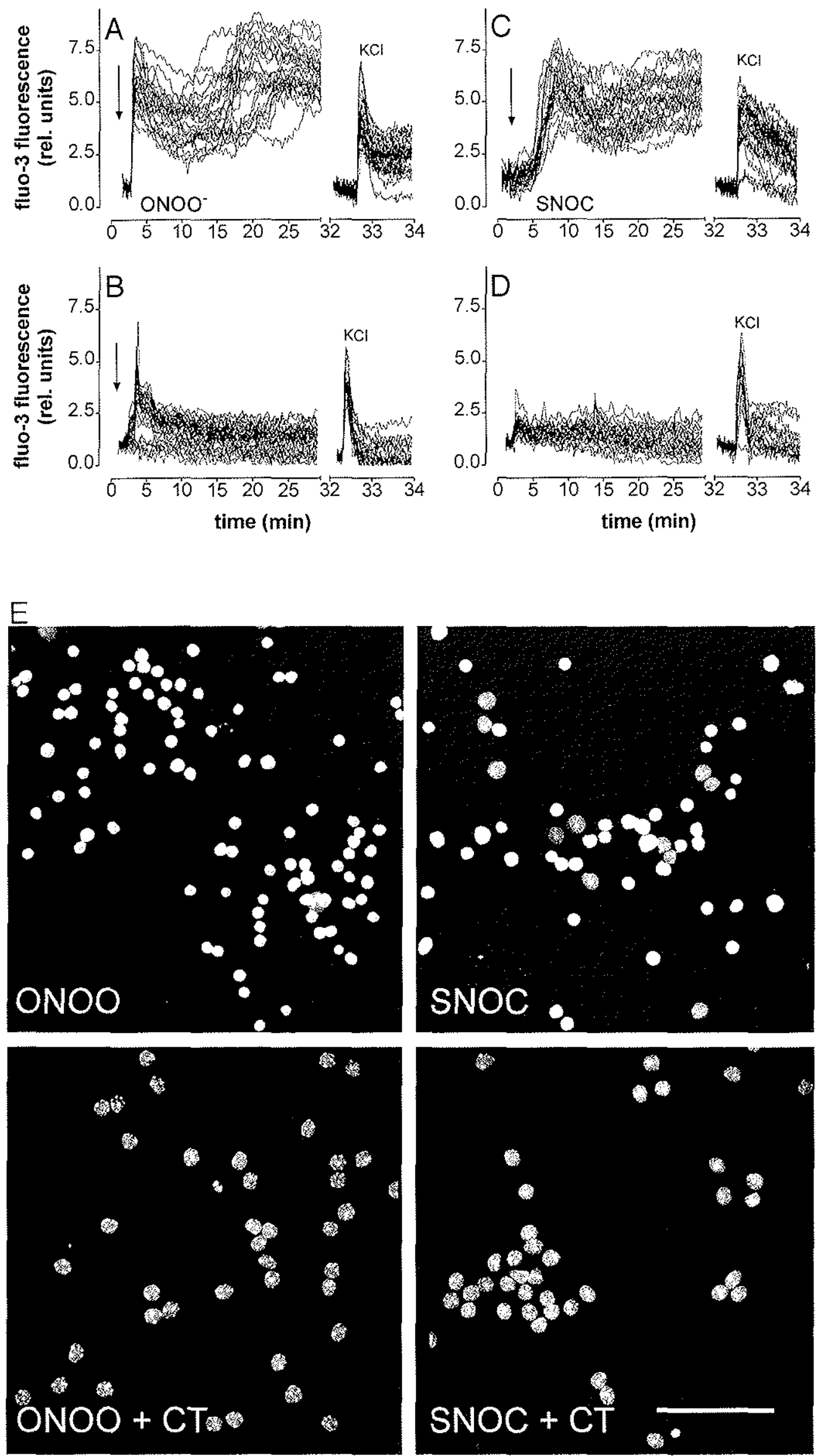


\section{Discussion}

In the present study we showed that exposure to $\mathrm{ONOO}^{-}$or nitric oxide induced apoptotic cell death in a population of synapticallylinked neurons by stimulating autocrine/paracrine excitotoxicity.

Our interpretation of ONOO/nitric oxide-induced cell death in CGC cultures as autocrine/paracrine excitotoxicity is based on the following findings. (i) The nitric oxide donors, as well as ONOO", selectively killed differentiated CGCs, which were also sensitive to NMDA toxicity, but not immature cells, which were insensitive to NMDA toxicity (i.e. during the early days in vitro). (ii) Apoptosis was associated with a sustained increase in $\left[\mathrm{Ca}^{2+}\right]_{i}$ and was dependent on extracellular $\mathrm{Ca}^{2+}$. The relative increases in $\left[\mathrm{Ca}^{2+}\right]_{i}$ were followed in real time in a large number of individual neurons under conditions of different pharmacological pretreatment and with different concentrations of $\mathrm{ONOO}^{-}$or nitric oxide donors. A sustained $\left[\mathrm{Ca}^{2+}\right]_{\text {; }}$ increase was observed only under conditions that resulted in neuron death. Similar correlations of cell death with relative changes in $\left[\mathrm{Ca}^{2+}\right]_{i}$ have also been observed in other paradigms of excitotoxicity (Choi, 1995). (iii) Apoptosis, as well as the increase in $\left[\mathrm{Ca}^{2+}\right]_{i}$, was prevented by blockers of the NMDA receptor. This suggests that $\mathrm{Ca}^{2+}$ influx was triggered by stimulation of this recepto: Further, prevention of the ONOO-induced increase in $\left[\mathrm{Ca}^{2+}\right]_{i}$ by the competitive antagonist APV implies that $\mathrm{ONOO}^{-}$induced the release or facilitated the action of an endogenous receptor agonist. In agreement with electrophysiological data (Fagni et al., 1995), this suggests that the nitric oxide donors did not open NMDA receptor channels directly. Prevention of toxicity by the NMDA receptor antagonists also argues for the causal involvement of NMDA receptor-mediated $\mathrm{Ca}^{2+}$ influx in $\mathrm{ONOO}^{-} /$nitric oxide toxicity. (iv) Clostridial toxins that block exocytosis also protected $\mathrm{CGC}$ from the increase in $\left[\mathrm{Ca}^{2+}\right]_{\mathrm{i}}$ and apoptosis elicited by ONOO-/nitric oxide.

The accumulation of a mediator that stimulates the NMDA receptor in this system can be explained either by nitric oxide-stimulated neurotransmitter release (O'Dell et al., 1991; Hirsch et al., 1993; Meffert et al., 1994, 1996; West and Galloway, 1996), e.g. glutamate, or by a possible direct or indirect nitric oxide-induced block of neurotransmitter reuptake (Nicholls and Attwell, 1990). Our experiments with a pharmacological blocker of glutamate reuptake showed that an increase in endogenously released excitatory amino acids is sufficient to induce apoptosis in CGC cultures. However, the more rapid onset of apoptosis and the quick increase in $\left[\mathrm{Ca}^{2+}\right]_{j}$ after exposure to $\mathrm{ONOO}^{-/ n i t r i c}$ oxide support the assumption that stimulated neurotransmitter release rather than just passive accumulation was involved. This conclusion is further supported by the experiments with the clostridial toxins (see below). The experiments in which reduction of the number of neurons did not modify the cytotoxic paradign observed in normal cultures (i.e. nitric oxide still caused apoptosis which was prevented by NMDA receptor antagonist and clostridial toxins) suggest that cell death here was probably mediated by a specific synaptic mechanism rather than by gencralized netrotransmitter release.

Perhaps the best evidence for the involvement of exocytosis in ONOO/nitric oxide-mediated CGC apoptosis is the effect of the clostridial toxins (Montecucco and Schiavo, 1995). Tetanus toxin and botulinum neurotoxin specifically interfere with the mechanism of vesicle fusion at the presynaptic membrane. In the presence of the clostridial toxins, neurons were consistently and entirely protected from concentrations of $\mathrm{ONOO}^{-}$or nitric oxide donors that otherwise caused up to $90 \%$ apoptosis in CGC cultures.

The chemical nature of the putatively released excitotoxic mediator has not been identified. Partial protection by a glutamate-removing enzyme system suggests the involvement of glutamate itself. As in the excitotoxicity due to exposure of cells to HIV gpl20 (Lipton, 1992), hypoxia (Cheng and Mattson, 1992; Monyer ef al., 1992a) or increased extracellular $\mathrm{Ca}^{2+}$ (Sucher et al., 1991), the contribution of other mediators remains an open question.

In cortical culures, nitric oxide synthase-containing neurons have been shown to be relatively resistant to the direct toxicity of nitric oxide and its putative metabolite $\mathrm{ONOO}^{-}$(Koh and Choi, 1988; Dawson et al., 1993). Since CGC express brain nitric oxide synthase, they may also be relatively resistant to toxic mechanisms directly triggered by nitric oxide, such as poly-(ADP-ribose) synthase activation (Zhang et al., 1994). Indeed, we found that $S$-nitrosocysteine concentrations ten times higher than those needed to elicit apoptosis in $95 \%$ of all CGC did not affect cultures pretreated with MK-801. Thus, cells which express NMDA receptors should be more sensitive to ONOO toxicity than cells in which this reccptor subtype is lacking, sucl as glial and PC-12 cells (Estćvez et al., 1995).

In view of these considerations it seems likely that in neurons nitric oxide may exert its toxicity by multiple and eventualy synergistic mechanisms. For example, nitric oxide could cause cytotoxicity directly by acting on DNA and proteins in sensitive cclls, sensitize certain neuron populations to further excitotoxic cliallenge, and trigger the release of excitotoxic neurotransmitters. Our observations show that the last mechanism is predominant in CGC cultures. This is in line with findings in different neuronal cells showing that nitric oxide alone, even at concentrations that fully activated guanylate cyclase, was not directly cytotoxic (Lafon-Cazal et al., 1993a; Zinkland et al., 1993; Hewett et al., 1994). Accordingly, endogenous nitric oxide generation from bNOS does not seem to further contribute to the excitotoxic mechanism described here. However, in our conditions the contribution of endogenous nitric oxide generation may be obscured by the presence of saturating concentrations of exogenous nitric oxide/ONOO- ${ }^{-}$. It is conceivable that prolonged activation of the endogenous nitric oxide synthase would otherwise contribute to the demise of CGC (Lafon-Cazal et al., 1993b; Marcaida et al., 1995).

Often, the diverse effects of nitric oxide donors on neuron survival in different culture systems have been explained by the redox state and chemical nature of nitric oxide or its metabolites (Lipton et al., 1993). A special role has been attributed to ONOO-" as a teminal mediator of toxicity, compared with other, less reactive nitric oxide congeners. The present study shows clearly that direct exposure of neurons to $\mathrm{ONOO}^{-}$does not result in non-specific breakdown of cellular homeostasis leading to immediatcly lethal events. Rather, $\mathrm{ONOO}^{-}$seems to act by an indirect but specific mechanism (i.e. by stimulating the exocytosis of excitatory neurotransmitters). The recruitment of a physiological pathway to initiate neuron demise in cells exposed to increasing nitric oxide levels suggests that the threshold between fine-tuning of neuronal responses [i.e. nitric oxidestimulated neurosecretion (Meffert et al., 1994)] and neuron injury may simply be decided by the nitric oxide/ONOO concentration. Accordingly, it has been shown that the mode of cell death also depends on the intensity of the insult (Bonfoco ef al., 1995).

In conclusion, pathological situations may be conceived in which imbalances in nitric oxide production and in the release/reuptake of excitatory amino acids would create a vicious circle forming the basis of subsequent neurodegeneration.

\section{Acknowledgements}

We are grateful for the excellent technical assistance of Ms H. Naumann and Mr T. Schnitz. This work was supported by grants from the Eutopean Community (EV5V CT94 0508), by the University of Konstanz AFF (grant 27/95), and by Telcthon-Italia (grant 763). 


\section{Abbreviations}

$\begin{array}{ll}\text { APV } & \text { D-2-amino-5-phosphonovaleric acid } \\ \text { BME } & \text { Eagle's Basal Medium } \\ \text { COC } & \text { cerebellar granule cell(s) } \\ \text { CSS } & \text { controlled salt solution } \\ \text { DIV } & \text { days in vitro } \\ \text { EH-1 } & \text { eftidium homodimer-1 } \\ \text { Fluo-3-AM } & \text { acetoxymethyl ester of fluo-3 } \\ \text { MK-801 } & (+)-5 \text {-methyl-10,11-dihydro-5H-dibenzo[a,d]cyclohepten- } \\ & 5,10 \text {-imine } \\ \text { MTT } & 3 \text {-(4,5-dimethylthiazole-2-yl)-2,5-diphenyltetrasodium } \\ & \text { bromide } \\ \text { SNAP } & S \text {-nitroso- } N \text {-acetyl-penicillamine }\end{array}$

\section{References}

Bagetta, G., Nisticò, G. and Bowery, N. G. (1990) Prevention by the NMDA receptor antagonist of neuronal loss produced by tetants toxin in the rat hippocampus. Br. J. Pharmacol, 101, 776-780.

Beckman, J. S., Beckman, T. W., Chen, J., Marshall, P. A. and Frecman, B. A. (1990) Apparent hydroxyl radical production by peroxynitrite: implications for cndothelial injury from nitric oxide and superoxide. Proc. Natl Acad. Sci. USA, 87, 1620-1624.

Beckmann, J. S., Ye, Z. Y., Anderson, P. G., Chen, J., Accavitti, M. A., Tarpey, M. M. and White, C. R. (1994) Extensive nitration of protein tyrosines in human atherosclerosis detected by immunohistochemistry. Biol. Chem. Hoppe-Seyler, 375, 81-88.

Beckman, 3. S., Chen, J., Ischiropoutos, H. and Crow, J. P. (1995) Oxidative chemistry of peroxynitrite. Methods Enyzmol, 233, 229-240.

Bolanos, J. P., Heales, S. J. R., Land, J. M. and Clark, J. B. (1995) Effect of peroxynitrite on the mitochondrial respiratory chain: differential susceptibility of neurones and astrocytes in primary culture. J. Neurochem., 64, 1965-1972.

Bonfoco, E., Leist, M., Zhivotovsky, B., Orrenius, S., L.jpton, S. A. and Nicotera, P. (1996) Cytoskeletal breakdown and apoptosis elicited by nitric oxide donors in cerebeliar granule cells require NMDA-receptor activalion. J. Neurochem., 67, 2484-2493.

Bonfoco, E., Krainc, D., Ankarcrona, M. Nicotera, P. and Lipton, S. A. (1995) Apoptosis and necrosis: two distinct events induced respectively by mild and intense insults with NMDA or nitric oxidc/superoxide in cortical cell cultures. Proc. Natl Acad. Sci. USA, 92, 72162-72166.

Bridges, R. J., Stanley, M. S., Anderson, M. W., Cotman, C. W. and Chamberlin, A. R. (1991) Conformationally defined neurotzansmitter analogues. Selective inhibition of glutamate uptake by one pyrrolidine-2,4-dicarboxylate diastereomer. J. Med. Chem., 34, 717-725.

Cheng, B. and Matson, M. P. (1992) IGF-I and IGF-II protect cultured hippocampal and septal neurons against calcium-mediated hypoglycemic damage. J. Neurosci, 12, 1558-1566.

Choi, D. W. (1995) Calcium: still centre-stage in hypoxic-ischemic neuronal death. Trends Neurosci. 18, 58-60.

Crow, J. P. and Beckman, 3. S. (1995) Reactions between nitric oxide, superoxide, and peroxynitrite: footprints of peroxynitrite in vivo. Adv. Phamacol., 34, 17-43.

Dawson, V. L., Dawson, T. M., London, E. D., Bredt, D. S. and Snyder, S. H. (1991) Nittic oxidc mediates glutamate neurotoxicity in primary cortical cultures. Proc. Nall Acad. Sci. USA, 88, 6368-6371.

Dawson, V. L., Dawson, T. M., Bartley, D. A., Uhl, G. R. and Snyder, S. H. (1993) Mechanisms of nitric oxide-mediated neurotoxicity in primary brain cultures. J. Neurosci., 13, 2651-2661.

Drejer, J., Bencviste, H., Diemer, N. H. and Schousboe, A. (1985) Cellular origin of ischemia-induced glutamate release from brain tissue in vivo and in vitro. J. Neurochem., 45, 145-151.

Estévez, A. G., Radi, R., Barbeito, L., Shin, J. T., Thompson, J. A. and Beckman, J. S. (1995) Peroxynitrite-induced cytotoxicity in PC12 cells: evidence for an apoptotic mechanism differentially modulated by neurotrophic factors. J. Neurochem., 65, 1543-1550.

Fagni, L., Olivier, M., Lafon-Cazal, M. and Bockaert, J. (1995) Involvement of divalent ions in the nitric oxide-induced blockade of $N$-methyl-D-aspartate receptors in cerebellar granule cells. Mol. Pharmacol., 47, 1239-1247.

Frandsen, A. and Schousboe, A. (1990) Development of excitatory amino acid induced cytotoxicity in cultured neurons. Int. $J$. Dev Neurosci, 8 , 209-216.

Garthwaite, J. and Boulton, C. L. (1995) Nitric oxide signaling in the central nervous system. Annu. Rev. Physiol., 57, 683-706.
Garthwaite, J., Southam, E., Boutton, C. L., Nielsen, E. B., Schmidt, K. and Maycr, B. (1995) Potent and selective inhibition of nitric oxide-sensilive guanylyl cyclase by $1 H-(1,2,4)$ oxadiazolo(4,3-a)quinoxalin-1-one. Mol. Pharmacol, 48, 184-188.

Gross, S. S. and Wolin, M. S. (1995) Nitric oxide: pathophysiological mechanisms. Annu. Rev. Physiol., 57, 737-769.

Hansson, E. and Rönnbäck, L. (1989) Ptimary cultures of astroglia and neurons from different brain regions. In Shahar, A., DcVellis, J., Vernadakis, A. and Haber, B. (eds), A Dissection and Tissue Culture Manual of the Nervous System. Wiley-Liss, New York, pp. 92-104.

Hart, T. W. (1985) Some observations concerning the $S$-nitroso and $S$-phenysulfonyl derivatives of L-cysteine and glutathione. Tetrahedron Lett., 26, 2013-2016.

Hewet, S. J., Csernansky, C. A. and Choi, D. W. (1994) Selective potentiation of NMDA-induced neuronal injury following induction of astrocylic iNOS. Neurn, 13, 487-494

Hirsch, D. B., Steiner, J. P., Dawson, T. M., Mammen, A., Hayek, E. and Snyder, S. H. (1993) Neurotransmitter release regulated by nitric oxide in PC-12 cells and brain synaptosomes. Curr. Biol., 3, 749-754.

Ischiropoulos, H., Zhu, L., Chen, 3., Tsai, M., Martin, J. C., Smith, C. D. and Beckman, J. S. (1992) Peroxynitrite-mediated tyrosine nitration catalyzed by superoxide dismutase. Arch. Biochem. Biophys., 298, 431-437.

Ishimaru, H., Katoh, A., Suzzki, H., Fukuta, T., Kameyama, T. and Nabeshima, T. (1992) Effects of $N$-methyl-D-aspartate receptor antagonists on carbon monoxide-induced brain damage in mice. J. Pharmacol. Exp. Ther, 261, $349-352$

Koh, J.-Y. and Choi, D. W. (1988) Vunerability of cultured cortical neurons to damage by excitotoxins: differential susceptibility of neurons containing NADPH-diaphorase. J. Neurosci., 8, 2153-2163.

Lafon-Cazal, M., Clucasi, M., Gaven, F., Pietri, S. and Bockaert, J. (1993a) Nitric oxide, superoxide and peroxynitrite: putative mediators of NMDAindaced cell death in cercbellar granule cells. Neuropharmacology, 32, 1259-1266.

Lafon-Cazal, M., Pietri, S., Culcasi, M. and Bockaert, J. (1993b) NMDAdepcndent supcroxide production and neurotoxicity. Nature, 364, 535-537.

Lei, S. Z., Pan, Z.-H., Aggarwal, S. K., Chen, H.-S. V., Yartman, J., Sucher, N. J. and Lipton, S. A. (1992) Effect of nitric oxide production on the redox modulatory site of the NMDA receptor-channcl complex. Newon, 8, 1087-1099.

Lin, K.-T., Xue, J.-Y., Nomen, M., Spur, B. and Wong, P. Y.-K. (1995) Peroxynitrite-induced apoptosis in HL-60 cclls. J. Biol. Chem., 270, $16487-16490$.

Lipton, S. A. (1992) Models of neuronal injury in AIDS: another role for the NMDA receptor? Trends Neurosci., 15, 75-79.

Lipton, S. A., Choi, Y.-B., Pan, Z.-H., Lei, S. Z., Chen, H.-S. V., Sucher, N. J., Loscałzo, J., Singel, D. J. and Stamier, J. S. (1993) A redox-based mechanism for the netroprotective and neurodestructive effects of nitric oxide and related nitroso-compounds. Nature, 364, 626-632.

Marcaida, G., Minana, M.-D., Grisolía, S. and Felipo, V. (1995) Lack of correlation between glutamate-induced depletion of ATP and neuronal death in primary cuitures of cerebellum. Brain Res., 695, 146-150.

Meffer, M. K., Premack, B. A. and Schulman, H. (1994) Nitric oxide stimulates calcium-independent synaptic vesicle release. Neuron, 12, 1235-1244.

Meffert, M. K., Calakos, N. C., Scheller, R. H. and Schulman, H. (1996) Nitric oxide modulates synaptic vesicle docking/fusion reactions. Neuron, 16, $1229-1236$.

Montecucco, C. and Schiavo, C. (1995) Structure and function of Tetanus and Botulinum neurotoxins. Q. Rev. Biophys. 28, 423-478.

Monyer, H., Giffard, R. G., Hartley, D. M., Dugan, L. L., Goldberg, M. P. and Choi, D. W. (1992a) Oxygen or glucose deprivation-induccd neuronal injury in cortical cell cultures is reduced by tetanus toxin. Neuron, 8 , 967-973.

Monyer, H., Sprengel, R., Schoepfer, R., Herb, A., Higuchi, M., Lomeli, H., Burnashev, N., Sakmann, B. and Seeburg, P. H. (1992b) Heteromeric NMDA receptors: molecular and functional distinction of subtypes. Science, 256, 1217-1221.

Mosmann, T. (1983) Rapid colorimetric assay for cellular growth and survival: application to proliferation and cytotoxicity assays. J. Immunol. Methods, $65,55-63$.

Nicholls, D. and Attwell, D. (1990) The release and uptake of excitatory amino acids. Trends Pharmacol. Sci., 11, 462-468.

O'Deil, T. J., Hawkins, R. D., Kandel, E. R. and Arancio, O. (1991) Tests of the roles of two diffusibje substances in long-term potentiation: evidence for nitric oxide as a possible early retrograde messenger. Proc. Natl Acad. Sci. USA, 88, 11285-11289. 
Piani, D., Spranger, M., Frei, K., Schaffner, A. and Fontana, A. (1992) Macrophage-induced cytotoxicity of $N$-methyl-D-aspartate receptor positive neurons involves excitatory amino acids rather than reactive oxygen intcrmediates and cytokines. Eur: J. Immunol, 22, 2429-2436.

Radi, R., Beckmann, J. S., Bush, K. M. and Freeman, B. A. (1991) Peroxynitrite oxidation of sulfhydryls. The cytotoxic potential of superoxide and nitric oxide. J. Biol. Chem., 266, $4244-4250$

Rossi, D. J. and Slater, N. T. (1993) The developmental onset of NMDA receptor-channel activity during neuronal migration. Neuropharmacology, 32, $1239-1248$.

Rothman, S. M. (1983) Synaptic activity mediates death of hypoxic neurons. Science, 220, 536-537.

Rothman, S. (1984) Synaptic relcase of excitatory amino acid neurotransmitter mediates anoxic neuronal death. $J$. Neurosci., 4, 1884-1891.

Sandberg, M., Butcher, S. P. and Hagberg, H. (1986) Extracellular overflow of neuroactive amino acids during severe insulin-induced hypoglycemia: in vivo dialysis of the rat hippocampus. J. Neurochem., 47, 178-184.

Schiavo, G. and Montecucco, C. (1995) Tetanus and Bolulinum neurotoxins: isolation and assay. Methods Enzymol., 248, 643-652.

Stamler, J. S. (1994) Redox signaling: nitrosylation and related target interactions of nitric oxide. Cell, 78, 93 $1-936$

Stamler, J. S., Simon, D. I., Osborne, J. A., Mullins, M. E., Jaraki, O., Michel, T., Singel, D. J. and Loscalzo, J. (1992a) S-nitrosylation of proteins with nitric oxide: synthesis and characterization of biologically active compounds. Proc. Natl Acad. Sci. USA, 89, 444-448.

Stamler, J. S., Singel, D. J. and Loscalzo, J. (1992b) Biochemistry of nitric oxide and its redox-activated forms. Science, 258, 1898-1902.
Sucher, N. J., Lei, S. Z. and Lipton, S. A. (1991) Calciurn channel antagonists attenuate NMDA receptor-mediated neurotoxicity of retinal ganglion cells in culture. Brain Res, 297, 297-302.

Troy, C. M., Derossi, D., Prochiantz, A., Greene, L. A. and Shelanski, M. L. (1996) Downregulation of $\mathrm{Cu} / \mathrm{Zn}$ superoxide dismutase lcads to cell death via the nitric oxide-peroxynitrite pathway. J. Neurosci., 18, 253-261.

Turski, L., Bressler, K., Retlig, K.-J., Löschmann, P.-A. and Wachtel, H. (1991) Protection of substantia nigra from $\mathrm{MPP}^{-}$neurotoxicity by $N$ methyl-D-aspartate antagoists. Nature, $349,414-418$.

West, A. R. and Galloway, M. P. (1996) Intrastriatal infusion of ( \pm$)-S$ nitroso- $N$-acetylpenicillamine releases vesicular dopamine via an ionotropic glutamate reccpto:-mediated mechanism: an in vivo microdialysis study in chloral hydrate-anesthetized rats. J. Neurochem., 66, $1971-1980$.

Wieloch, T. (1985) Hypoglycemia-induced neuronal damage prevented by an $N$-methyl.D-aspartate antagonist. Science, 230, 681-683.

Xia, Y., Ragan, R. E., Seah, E. E. C., Michaelis, M. L. and Michaelis, E. K. (1995) Developmental expression of $N$-methyl-D-aspartate (NMDA)-induced neurotoxicity, NMDA receptor function, and the NMDAR1 and glutamatebinding protein subunits in cerebellar granule cells in primary cultures. Neurochem. Res, 20, 617-629.

Zhang, J. and Snyder, S. H. (1995) Nitric oxide in the nervous system. Annu. Rev. Phamacol. Toxicol., 35, 213-233.

Zhang, J., Dawson, V. L., Dawson, T. M. and Snyder, S. H. (1994) Nitric oxide activation of poly(ADP-ribose) synthetase in neurotoxicity. Science, 263, 687-689.

Zinkland, W. C., Stumpo, R. Y., Thompson, C., Patel, J. and Pullan, L. M. (1993) Lack of involvement of nitric oxide in NMDA-induced neuronal cell death in cortical culture. NetroReport, 5, 148-50. 